\title{
ORGANIZATION OF INDIVIDUAL WORK AS A FORM OF EDUCATIONAL PROCESS AT HIGHER EDUCATIONAL INSTITUTIONS FOR DEVELOPING FOREIGN LANGUAGE PROFESSIONAL COMMUNICATION OF STUDENTS AQUIRING SPECIALTIES CONNECTED WITH THE TRANSPORT INDUSTRY
}

\author{
Makoviei R. H. ${ }^{1}$ \\ ${ }^{1}$ KhNUUE after O. M. Beketov
}

\begin{abstract}
Problem. In recent years, the interest towards the independent work in organizing the educational process in all courses of studying a foreign language at institutions of higher education has increased significantly. Considerable attention is paid to the issues of upbringing the personality of a modern specialist, one's competitiveness, and public responsibility. Goal. The goal of the article is to determine the specifics of independent work as an important form of the main direction and tasks of the educational process at the university for the development of foreign language professional communication of students of transport specialties. Methodology. Analysis of the problem of organizing the independent work as a form of educational process at institutions of higher education for the development of foreign language professional communication of students of transport specialties was conducted. There was accomplished the analysis of recent researches of scientists and it was revealed that the problem of organizing the independent work of students is prioritized and is expected to facilitate the revision of both the theoretical and methodological principles of modern training of competitive foreign language specialists.Results. It was established that the properly organized independent work of students of transport specialties increases the efficiency of management, control and selfcontrol by independent work; improves the cognitive activity of students; develops their logical and creative thinking of the concepts of the language being studied; forms a conscious attitude to the outside world and stimulates the interest in the originality of thinking in a foreign language. Originality. The author proposed the stages of organizing the independent work on the development of foreign language professional communication of students of transport specialties.Practical value. A competently organized independent work on foreign languge professional communication forms a foreign language communication competence, skills and abilities that ensure the acquisition of linguistic means, the definition of the communicative content of the understanding of individual linguistic units, their meanings, forms and structures, as well as the relationship between them.
\end{abstract}

Key words: independent work, modern specialist, educational process, higher education, specialized discipline, vocational training, professional skills, non-philology specialties.

\section{Introduction}

In recent years, the problem of independent work of students studying a foreign language at institutions of higher education is in a state of implementation both from the position of organization, as well as the methods of its most effective realization. In a non-philological higher educational institution, a foreign language, in professional terms, is not a specialized discipline being studied, and a limited number of academic hours create difficult conditions for studying it. Therefore, high motivation and active communication behavior of the student in the process of learning and the adequately organized independent work is the key to good knowledge, skills and abilities to be acquired while mastering a foreign language for all types of activities: listening, reading, speaking and writing.
The interest towards the independent work in organizing the educational process in all courses of studying a foreign language at institutions of higher education has increased significantly. Considerable attention is paid to the issues of upbringing the personality of a modern specialist, one's competitiveness, public responsibility, the formation and development of such features of a young person as independence, consciousness and activity.

\section{Research objective}

In the modern educational process, there is no problem more important and at the same time more complex than the organization of independent work of subjects of the educational process. The importance of this problem is related to the new role of independent work, which it 
acquires in connection with the transition to the educational activity paradigm. As a result of this transition, the independent work becomes the leading form of organization of the educational process, and with it the problem of its activation arises. Activation of independent work is not understood as a simple increase in the volume of academic hours.

At present, the independent work due to its insufficient targeting, weak control, insufficient differentiation and variability, in which the individual capacities, needs and interests of the subjects of the educational process are minimally taken into account, can not ensure the qualitative realization of the tasks assigned to it. Thus, to intensify the independent work in the educational process means to significantly increase its role in achieving new educational goals, giving it a problematic character, motivating the subjects of the educational process to treat it as the leading means of forming academic and professional competence [1]. The goal of the article is to determine the specifics of independent work as an important form of the main direction and tasks of the educational process at the university for the development of foreign language professional communication of students of transport specialties.

\section{Analysis of recent researches and publications}

Analysis of psychological and pedagogical literature allows us to clarify the essence of vocational training and to determine the role of independent work of students in a foreign language in the process of formation and development of professional skills in a specialty. The use of modern technologies in the educational process for the purpose of improving the study of foreign languages, in particular at higher educational institutions, has been studied by many scholars.

In work [1] it is emphasized that the independent work due to its insufficient targeting, weak control, insufficient differentiation and variability, in which the individual capacities, needs and interests of the subjects of the educational process are minimally taken into account, can not ensure the qualitative realization of the tasks assigned to it. Thus, to intensify the independent work in the educational process means to significantly increase its role in achieving new educational goals, giving it a problematic character, motivating the subjects of the educational process to treat it as the leading means of forming academic and professional competence.
Studying the independent work of future specialists of the non-philological profile, the author of work [2] interprets it as a sequence and interaction of stages for organizing the independent work of students to develop the professional communication. A competently organized independent work on foreign languge professional communication forms a foreign language communication competence, which, in the opinion of the scientist, forms a complex of knowledge, skills and abilities that ensure the acquisition of linguistic means, the definition of the communicative content of the understanding of individual linguistic units, their meanings, forms and structures, as well as the relationship between them. According to the author of work [3], the effectiveness of both the student and independent work depends on the organization, and the supervision by the teacher-consultant. The purpose of the supervision is to help the student to master the theoretical material and acquire the skills of solving certain practical problems methodically correct with the minimum amount of time wasted.

In work [4] it is mentioned that the organization of independent activity of students using the Internet involves the use of recent pedagogical technologies that stimulate the disclosure of the internal reserves of each student and simultaneously contribute to the formation of social and psychological qualities of the individual (selfconfidence and the ability to work in a team, performing various social roles, helping each other in joint activities, solving jointly complex cognitive tasks). The author of work [5] emphasizes that the main goals of organizing the independent work while teaching a foreign language to students of transport specialties lie in the formation of speech, training, professional competencies, the development of autonomy as a personality trait. The peculiarity of a foreign language as a discipline for future engineers is that during its study skills and abilities to use a foreign language as a means of communication, obtaining new, professionally relevant information are formed.

\section{The independent work of students as an important form, the main direction and task of the educational process at universities}

It should be noted that in recent years, the interest towards the independent work in the organization of the educational process at all stages of education has increased considerably. The doctrine of the active nature of the educational activity has currently become the foundation of 
the doctrine of the independent work of those who study. It is being developed in Ukraine at the joint efforts of many psychologists, educators and methodologists. In this regard, the methods and didactics of effective organization of the independent work of students studying a foreign language have become clearer.

The independent work of students is an important form, the main direction and task of the educational process at universities, because the development of autonomy as a trait of character is the most important in the structure of the person of a modern competitive specialist, which meets the requirements of both the society and the labor market for the development of foreign language professional communication of students of non-philology specialties, in particular transport ones.

The independent work of students is a type of cognitive activity, the subject of which is a student in the aggregate of his individual qualities as a future specialist who acquires knowledge of a foreign language for a professional orientation. The result of such independent work of students is the qualitative transformation of the personality of a specialist, the development of professional skills, and the individual style of future professional activities through the means of foreign language communication.

The independent work is a student's educational activity, which is planned and fulfilled through assignments with methodological guidance and under the supervision of a teacher, but without his direct participation.

A higher educational institution involves intensive independent work of students related to such types of educational activities as lectures, seminars, practical and laboratory work, individual tasks, practical training, preparation of reports for students' scientific conferences (visual and on-line), writing essays, course papers, theses, etc.

Among the types of educational activities of students of non-philological higher educational institutions one should focus attention on those used for foreign language training in order to formulate a communication culture by means of a foreign language in the unity of spiritual, professional, socio-cultural and psycholinguistic aspects of the development of professional communication of students, formation of needs and motives in mastery of communication knowledge, abilities and skills of foreign language professional communication. These tasks involve intense and conscious self-employment of students.
I. Drozdova, studying the independent work of future specialists of the non-philological profile, interprets it as a sequence and interaction of stages of the organization of independent work on the development of professional communication [2]. A competently organized independent work on foreign languge professional communication forms a foreign language communication competence, which, in the opinion of the scientist, forms a complex of knowledge, skills and abilities that ensure the acquisition of linguistic means, the definition of the communicative content of the understanding of individual linguistic units, their meanings, forms and structures, as well as the relationship between them. This activity is organized by stages.

Stages of organizing the independent work on the development of foreign language professional communication of students of transport specialties are clearly presented in Table 1.

Table 1 - Stages of independent work on the development of foreign language professional communication of students of transport specialties

\begin{tabular}{|c|c|}
\hline $\begin{array}{c}\text { I stage } \\
\text { (propaedeutic) }\end{array}$ & $\begin{array}{l}\text { - rationing } \\
\text { - planning } \\
\text { - organization }\end{array}$ \\
\hline II stage (basic) & $\begin{array}{l}\text { - educational and meth- } \\
\text { odological support of }\end{array}$ \\
\hline $\begin{array}{l}\text { III stage (theoreti- } \\
\text { cal/practical) } \\
3 \text { Practical) практи- } \\
\text { чний) }\end{array}$ & $\begin{array}{l}\text { - auditorium and non- } \\
\text { auditorial IWS }\end{array}$ \\
\hline IV stage (control) & $\begin{array}{l}\text { control } \\
\text { - self-monitoring } \\
\text { - self-examination } \\
\end{array}$ \\
\hline V stage (correction) & $\begin{array}{l}\text { - correction of the educa- } \\
\text { tional process (teacher) } \\
\text { - self-correction }\end{array}$ \\
\hline
\end{tabular}

Forms of independent work of students of transport specialties are aimed at the development of foreign language professional communication, including the work with literary sources (textbooks, manuals, reference books, dictionaries), writing essays, preparing reports, performing creative tasks, participating in scientific conferences, training, business games and many more.

Let's show how to organize the independent work of students of transport specialties for the development of foreign language professional communication in the structure of the course "The English Language (in professional orientation)".

It should be noted that the didactic complex for teaching a foreign language should combine 
conventional, traditional methods including the methods of interactive learning. This creates a learning situation in which the student prefers to independently study, consolidate and activate the linguistic material, and the formation of communication skills and abilities is carried out under the direct guidance of the teacher.

The following types and forms of independent work of students and some of the latest approaches to its organization can be perceived or not perceived by certain teachers, but they are to some extent a guideline in determining the methodological approaches and methods of delivering classes. They are such as the organization of work with audio and video teaching materials, various activities in the context of communicative, professionally oriented, project methods - the approaches established in didactic and teaching methods of foreign languages as the most progressive, role-playing game, Internet conferences (on-line conferences), the use of multimedia and electronic textbooks, as well as the use of textbooks, supplementary materials through mobile devices (phones, tablets), on-line conferences, events in which students do not only take an active part, but they can also hold such activities themselves. The effectiveness of both the student and independent work depends on the organization, and the supervision by the teacher-consultant. The purpose of the supervision is to help the student to master the theoretical material and acquire the skills of solving certain practical problems methodically correct with the minimum amount of time wasted [3].

Preparation for curricula classroom activities.

The forms of independent work of students are as follows: 1) study of compulsory and additional literature, texts of lectures, etc. (creation of the appropriate information base in printed and electronic forms according to the modules (textbooks, lecture notes, etc.); the selection of effective methods for assessing students' activity. To pay attention to the students' abilities to work independently, use a computer, create motivational and organizational preconditions (to show the real prospect of using this knowledge when implementing one type of IWS).

The forms of supervision and reporting:

1) Active participation in various types of classroom activities.

2) Preparation for practical and seminary classes for the purpose of creating informational and methodological support (methodical recommendations for independent preparation of students for carrying out practical and seminar classes with indication of additional and basic literature, the content of control questions and independent tasks, etc.; the type of supervision consists in the implementation of practical work and verification of its writing by the teacher; the student motivation lies in the avoidance of failure, desire for knowledge).

The forms of control and reporting: active participation of students in practical classes and seminars, drawing up a report of the corresponding forms of work.

Organization of independent activity of students using the Internet involves the use of recent pedagogical technologies that stimulate the disclosure of the internal reserves of each student and simultaneously contribute to the formation of social and psychological qualities of the individual (self-confidence and the ability to work in a team, performing various social roles, helping each other in joint activities, solving jointly complex cognitive tasks) [4].

The main goals of organizing independent work while teaching a foreign language to students of transport specialties lie in the formation of speech, training, professional competencies, the development of autonomy as a personality trait. The peculiarity of a foreign language as a discipline for future engineers is that during its study skills and abilities to use a foreign language as a means of communication, obtaining new, professionally relevant information are formed. The specificity of the goals of independent work in a foreign language determines the peculiarities of methods, means and forms of its organization, which vary depending on the stage, content and the teaching tasks with the help of information technologies [5].

In addition, the Internet provides a wide range of opportunities for organizing various educational projects. There are two types of projects: WWW projects, E-mail projects. WWW projects are designed for students to receive tasks for which they need to find information via the Internet and then submit their search results.

When forming an independent educational activity using the Internet resources it is necessary that the linguistic material should be emotionally colored, have a purposeful value, taking into account the professional preferences of the students. In order to achieve the emotional color of teaching a foreign language, it is necessary to alternatively use various types of educational activity, including the educational process of communicative activity, the use of cognitive and authentic texts. In the process of working with the Internet resources, students will get acquainted with country-specific information, cultural aspects of the language of the country be- 
ing studied, as well as personalized websites of renowned specialists, etc.

Let's consider the model of organizing the independent work of students of HEI on the basis of using the teacher's personal website as a centralized means of Internet technologies integration into the process of foreign language training of specialists. Such a model can be used for organizing the independent work of students of different specialties.

In the process of organizing the independent work it was discovered that:

1) Integration of the possibilities provided by the Internet in the process of professional foreign language training of students of HEI promotes the improvement of the quality of the educational process, optimization and intensification of the process of learning a foreign language, as well as the formation of foreign language professional communication skills of students oftransport specialties.

2) Effective integration of the Internet is achieved through the use of the teacher's personal language web-site as a centralized one for providing web-based training technologies for the purpose of organizing students' independent work and supporting the learning process.

3) The independent work of students is implemented with the help of their participation in specially developed activities for teaching a foreign language: independent work with electronic resources and the Internet communication. The personal web site of a foreign language teacher, using the information and communication services of the Internet, makes it possible to effectively organize the independent work of students and supervise it, as well as provides students with various information, which increases the availability and quality of education.

4) The structure and services of the website allow adapting its information content to the goals and objectives of the educational process at institutions of higher education, to take into account the individual characteristics and specific needs of both the student and the teacher, as well as provide constant feedback.

\section{Conclusions}

Analysis of the problem of organizing the independent work as a form of educational process at institutions of higher education for the development of foreign language professional communication of students of transport specialties revealed that it is a priority in many researches of scientists and should facilitate the revision of both the theoretical and methodological princi- ples of modern training of competitive foreign language specialists. It is obvious that the independent work on the course of foreign language by professional direction requires content, organizational and methodological improvement, as well as the improvement of organizing the educational process, oriented to achieve the goal. The properly organized independent work of students of transport specialties increases the efficiency of management, control and selfcontrol by independent work; improves the cognitive activity of students; develops their logical and creative thinking of the concepts of the language being studied; forms a conscious attitude to the outside world and stimulates the interest in the originality of thinking in a foreign language.

The prospects of further investigation in the field of scientific research are seen in the development of effective areas for the purpose of further improvement of the process of teaching foreign languages by professional orientation through distance learning of students, intensification of research activities, using information and communication technologies.

\section{References}

1. Семенова В. Г. Самостійна робота студентів як найуважливіша форма організаційної роботи навчально-виховного процесу в рамках компетентної моделі навчання. Організація самостійної роботи студентів: матеріал IIзагальнонародної науково-практичної інтернет-конференції. Саратов: Новий Проект. 2013. C. 10-15.

2. Дроздова I. П. Наукові основи формування української професійної творчості студентів нефілологічних факультетів вищих навчальних закладів: монохрефія. Харків, $K C A M E$. 2010. 320 c.

3. Пасов Е.І., Комунікативний метод здійснення інозумної мілки сплівки. 2-е видання. Москва: Проспект. 1991. 223 с.

4. Livingstone C. Role-play in language learning/C. Livingstone. - London, 1983, 95.

5. Мікітенко Н.О., Терещук Г. В. Теоретичні основи формування інозної сфери професійної компетенції майбутніх спеціалістів 3 науководослідних наук: монографія. Тернопіль: ТНПУ. 2011. 384 с.

6. Маковєй Р. Г. Самостійна робота як форма навчального процесу у ВНЗ для розвитку іншомовного професійного мовлення студентів транспортних. Наукові записки Бердянського державного педагогічного університету. Серія: Педагогічні науки. Бердянськ: Видавництво ПП Лисенко М. М. 2017. С. 159-164. 


\section{References}

1. Semenova V. H. (2013). Samostiyna robota studentiv yak nayvazhlyvisha forma orhanizatsiyi navchal'no-vykhovnoho protsesu $\mathrm{v}$ ramkakh kompetentnoyi modeli navchannya [The independent work of students as the most important form of of the educational process organization within the framework of a competent model of education]. Orhanizatsiya samostiynoyi roboty studentiv: materialy II-zahal'norosiys'koyi naukovo-praktychnoyi internet-konferentsiyi. Saratov: Novyi Proekt, 10-15 [in Russian].

2. Drozdova I. P. (2010). Naukovi osnovy formuvannya ukrayins'koyi profesiynoyi movy dlya studentiv nefilolohichnykh fakul'tetiv vyshchykh navchal'nykh zakladiv: [Scientific fundamentals of the formation of Ukrainian professional language for students of non-philological faculties of higher educational institutions]. Monohrafiya Harkiv, KSAME [in Ukrainian].

3. Pasov E. I. (1991). Komunikatyvnyi metod vykladannya inozemnoyi movy spilkuvannya [Communicative method of teaching foreign language communication]. E.I. Pasov - 2-e vydannya. Moskva.: Prosveshchenye [in Russian].

4. Livingstone C. (1983). Role-play in language learning/C. Livingstone. - London, 95.

5. Mikitenko N.O. (2011). Teoretychni osnovy formuvannya inozemnoyi movy profesiynoyi kompetentnosti maybutnikh spetsialistiv $\mathrm{z}$ pryrodnychykh nauk [Theoretical basis of formating foreign language professional competence of future specialists in natural sciences]. Monohrafiya / N.O. Mykytenko /za red. d. ped. nauk, Profesor, chlen-korespondent Natsional'noyi akademiyi nauk Ukrayiny H.V. Tereshchuk. Ternopil': TNPU [in Ukrainian].

6. Makovyey R.H. (2017). Samostiyna robota yak forma navchal'noho protsesu u VNZ dlya rozvytku inshomovnoho profesiynoho movlennya studentiv transportnykh spetsial'nostey [The independent work as a form of the educational process at the university for the development of foreign language professional communication of students of transport specialties]. Naukovi zapysky Berdyans'ks'koho derzhavnoho pedahohichnoho universytetu. Seriya: Pedahohichni nauky Berdyans'k: Vydavnytstvo PP Lysenko M.M., 159164 [in Ukrainian].

Makoviei Radul Hryhorovych ${ }^{\mathbf{1}}$, Senior Lecturer, Department of Foreign Languages,

$$
\text { tel.: } \quad+38
$$

radumakovyey@gmail.com,

096-299-83-60,

${ }^{1}$ O. M. Beketov National University of Urban Economy, 17 Marshal Bazhinov Str., 61002, Ukraine, Kharkiv.
Організація самостійної роботи як форми навчального процесу у внз для розвитку іншомовного професійного мовлення студентів транспортних спеціальностей

Анотація. У статті подається аналіз самостійної роботи студентів транспортних спеціальностей ВНЗ як важливої форми навчального процесу з метою розвитку й удосконалення іншомовного професійного мовлення. Визначено й схарактеризовано форми, етапи, обтрунтовано методику й дидактичні засоби ефективної організаиії самостійної роботи студентів, щзо передбачає переорієнтацію з лекиійної форми здобуття інформації на індивідуально-диферениіиовану форму, орієнтовану на особистість студента, логічну й усвідомлену організацію його самоосвіти. Передбачено, щзо зовнішній контроль за самостійною роботою з боку викладачів має поєднуватися з самоконтролем студентів. Зазначено, щзо викладач визначає послідовність вивчення й засвосння навчально-методичного матеріалу 3 іноземної мови за фахом студентів. За кожною темою практичних занять студенти відпрацьовували вміння складати різні за жанрами наукові й ділові тексти за фахом в усному або писемному мовленні, набуваючи таким чином комунікативні навички іншомовного професійного мовлення. Правильно організована самостійна робота студентів дозволяє підвищити загальнофахову обізнаність із майбутньою професією, рачіонально користуватися довідково-бібліографічним апаратом наукової літератури, здійснювати своєчасний контроль у процесі оволодіння лексикостилістичними засобами наукового й офіційноділового стилів англійської мови. Формування професійних знань і вмінь, розвиток організаційних та комунікативних якостей особистості напряму залежать від ефективної самостійної роботи майбутнього фахівия транспортних спеиіальностей. Організаиія самостійної роботи студентів з іноземної мови за професійним спрямуванням обов'язково має враховувати основні тендениії в розвитку сучасної методики навчання іноземних мов: комунікативну спрямованість, активізацію мовленнєвої й мисленнєвої діяльності студентів у прочесі оволодіння мовою як засобом спілкування, підвищення мотивачії навчання, індивідуальний підхід до студентів $і$ розвиток інтересу до предмету й майбутньої професії.

Ключові слова: самостійна робота, розвиток іншомовного професійного мовлення, студенти транспортних спеціальностей, форми самостійної роботи студентів, етапи самостійної роботи студентів.

Маковсй Радул Григорович ${ }^{1}$, старший викладач кафедри іноземних мов, тел .: +38 096-299-83-60, radumakovyey@gmail.com,

${ }^{1}$ Харківський національний університет міського господарства ім. О. М. Бекетова, вул. Маршала Бажинова, 17, 61002, Україна, м. Харків. 
Организация самостоятельной работы как формы учебного процесса в вузе для развития иноязычной профессиональной речи студентов транспортных специальностей

Аннотация. В статье проводится анализ самостоятельной работы студентов транспортных специальностей ВУЗ-ов, как важной формы учебного прочесса с иелью развития и совершенствования иноязычной профессиональной речи. Определены и охарактеризованы формы, этапь, обоснована методика и дидактические средства эффективной организации самостоятельной работы студентов.
Ключевые слова: самостоятельная работа, развитие иноязычной профессиональной речи, студенты транспортных специальностей, формьл самостоятельной работь студентов, этапь самостоятельной работы студентов.

Маковей Радул Григорьевич ${ }^{1}$, старший преподаватель кафедры иностранных языков, тел.: +38 096-299-83-60, radumakovyey@gmail.com,

${ }^{1}$ Харьковский национальный университет городского хозяйства им. А. Н. Бекетова, ул. Маршала Бажинов, 17, 61002, Украина, г. Харьков. 